Working Paper n. 01 - 2012

\title{
FIRM SIZE AND WAGES IN ITALY: EVIDENCE FROM EXOGENOUS JOB DISPLACEMENTS
}

\author{
Vincenzo Scoppa \\ Dipartimento di Economia e Statistica \\ Università della Calabria \\ Ponte Pietro Bucci, Cubo 0/C \\ Tel.: +390984 492464 \\ Fax: +390984 492421 \\ e-mail:v.scoppa@unical.it
}

\section{Gennaio 2012}

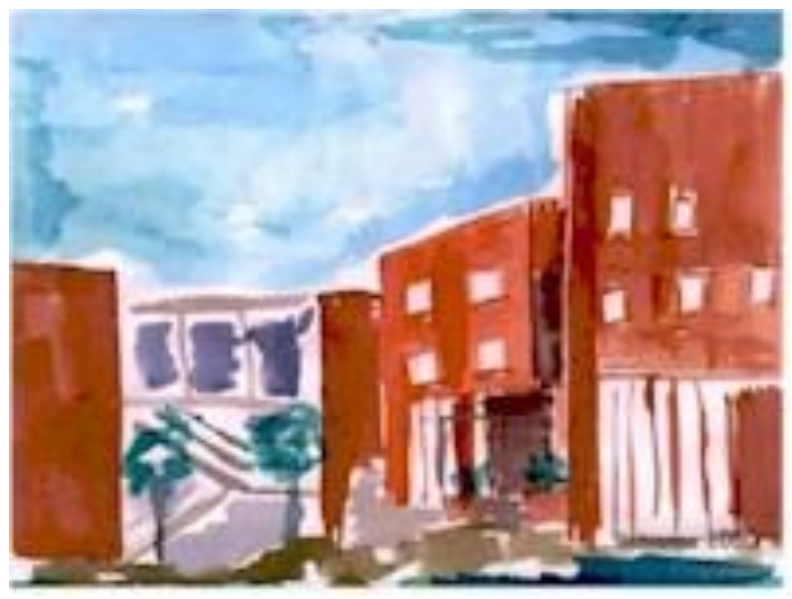




\title{
Firm Size and Wages in Italy:
}

\section{Evidence from Exogenous Job Displacements}

\author{
Vincenzo Scoppa*
}

This version: 27 January 2012

\begin{abstract}
We use longitudinal data based on administrative archives from 1985 to 2002 to estimate the relationship between wages and firm size for Italy. Controlling for individual fixed effects we find that larger firms pay significantly higher wages, although the individual unmeasured ability component accounts for about one half of the uncovered size-wage premium. To reduce potential self-selection problems arising from endogenous job changes, we focus on a sample of workers displaced by plant closings. Using this sample, we confirm that larger firms pay higher wages in part for unmeasured workers' abilities and in part for true size effects.
\end{abstract}

JEL classification: J41; M51; J45.

Keywords: Wages; Firm Size; Wage Differentials; Panel Data; Exogenous Job Changes;

\section{Introduction}

The positive relationship existing between firm size and wages is by now well documented in the empirical literature: workers with the same observable characteristics are paid a wage significantly higher in larger firms (see, among others, Brown and Medoff, 1989; Winter-Ebmer and Zweimüller, 1999; Abowd, Kramarz, Margolis, 1999; Manning, 2003). For example, in their seminal paper, Brown and Medoff (1989) find that in the US an employee in a large firm (that is, with 500 or more employees) gains $35 \%$ percent more than an employee with the same observable characteristics employed in a small firm. The large employer wage premium is similar in magnitude to the race or gender wage premium.

However, there is no consensus in the literature on the source of the observed wage premium for large firms. The main controversy hinges upon whether the large firm premium is due to unobserved workers' productive abilities (for observationally equivalent workers) or whether it is due to some employer's characteristics. As Gibson and Stillman (2009) puts it "in light of the conflicting views on the worker quality explanation, more evidence is needed".

The economic theory has offered a variety of explanations for the large firm wage premium: 1) compensations for higher workers' skills; 2) “compensating wages" probably because of less

\footnotetext{
* Department of Economics and Statistics, University of Calabria, Arcavacata di Rende (CS), Italy. E-mail: v.scoppa@unical.it. I am extremely grateful to the Laboratorio Revelli and to the Fondazione Rodolfo Debenedetti for making available the two datasets used in this paper. I would like to thank Giorgio Brunello, Maria De Paola, Michela Ponzo and Giovanni Sulis for useful comments and suggestions.
} 
attractive working conditions in large firms; 3) rent sharing, since large firms have typically higher monopoly power and, consequently, higher profits that firms may share with their workers); 4) "efficiency wages" considerations, monitoring being more difficult and shirking presumably more costly in larger firms.

Understanding the source of the wage premium is also relevant because the explanations related to the unobserved workers' abilities and to the compensating wage differentials may be reconciled with competitive models of labor markets, while the other factors are in contrast to them.

The issue of whether workers' unobserved traits are responsible for firm size wage differentials is strictly related to the use of econometric estimators that allow to identify a causal effect of firm size. The use of an OLS estimator with cross-sectional data clearly leads to an upward bias if unobservable abilities are positively correlated to firm size. Two alternative methods have been undertaken to avoid estimation biases: the adoption of a selection model explaining the sorting of workers across employers of different sizes and the use of fixed effects estimators with longitudinal data. Neither of these two methods is immune from problems.

Idson and Feaster (1990) for US, Main and Reilly (1993) for UK, and Brunello and Colussi (1998) for Italy estimate with cross-sectional data the size-wage effect with a two-step procedure: first, they take into account the non-random sorting of workers across different-size employers, estimating a selection equation to predict the distribution of employees in different firm size categories, and then add the selection term into the wage equation (Heckman, 1976; Lee, 1978). This procedure is a substitute for an instrumental variable (IV) estimation strategy (with an instrument for firm size) that the authors are forced to follow since in their data firm size is a categorical variable making unpractical the use of an IV estimator.

Correcting for the potential selection bias - using typically marital status and number of children as identifying variables for firm size - Idson and Feaster (1990) and Main and Reilly (1993) find a considerable wage premium for large firms, while Brunello and Colussi (1998) find no wage premium for Italian workers once the observed characteristics and selection effects have been taken into account.

Winter-Ebmer and Zweimüller (1999) study the Swiss labor market focusing on job changers and controlling for sample selectivity to attenuate the endogeneity problem. They find that about onehalf of the large firm wage premium is due to worker heterogeneity.

Albæk et al. (1998), thanks to the availability of a continuous measure of firm size, are able to use a more standard IV strategy. Their TSLS estimates find that selection effects are little relevant but their over-identification tests reject the validity of the instruments. They are in general skeptical on the possibility of obtaining exogenous and relevant instruments for firm size to deal with potential selection effects.

The alternative estimation strategy followed to avoid self-selection problems consists in the use of a fixed effects estimator with panel data. Brown and Medoff (1989) using longitudinal data find 
that firm size wage differentials are partially due to the presence of higher quality workers in large firms: the size wage differentials are reduced by 5-45 percent when using individual fixed effects. On the other hand, Abowd, Kramarz and Margolis (1999) using a large matched employer-employee dataset from France find that individual heterogeneity accounts for almost all the wage variations between size categories, while firm heterogeneity contributes for a negligible fraction.

However, as argued by Solon (1988) and Gibbons and Katz (1992), fixed effects estimates are based on the assumption that job changes are exogenous. In contrast, if workers' decisions to move is voluntary, there could be a self-selection problem and fixed effects estimates are inconsistent.

Finally, a number of empirical works use matched employer-employee data set (Troske, 1999; Albæk et al., 1998; Schmidt and Zimmermann, 1991; Arai, 2003, Lallemand, Plasman and Rycx, 2007; Pedace 2010) trying to explain the firm size wage differential putting it in relation with a number of employers' characteristics: physical capital intensity (to test if skill-capital complementarity is relevant), profits (for the rent sharing hypothesis), working conditions (to verify if firms pay compensating wage differentials), monitoring (testing efficiency wages theories), workforce skills, unionization and so on. Typically, these studies find that physical capital, profits and skill complementarity are important determinants of wage differentials, although a large part of the differentials remains unexplained. ${ }^{1}$

The aim of this paper is to estimate for Italian workers the magnitude of the employer-size wage effect using panel data. To further investigate the extent of self-selection problems in fixed effects estimates we use a sub-sample of workers displaced by plant closings. We follow the approach of Gibbons and Katz (1992) that in their analysis of inter-industry wage differentials propose the selection of a sample of workers displaced by the closure of their firm. The focus on exogenous movers should reduce the incidence of self-selection bias.

We use two large datasets based on Social Security administrative records - the Work Histories Italian Panel (WHIP) and the dataset "Fondazione Rodolfo Debenedetti" (FRDB) - with more than 700,000 observations with information on workers' and employers' characteristics (wage, gender, age, occupation, seniority, geographical area, size, industry, etc.). While WHIP is a long panel (workers are followed for 18 years), the advantage of FRDB dataset is the information on the firm status (if the firm is active or has been closed).

Controlling for individual fixed effects we find that larger firms pay significantly higher wages, although the individual unmeasured ability component accounts for about one-half of the uncovered size-wage premium: a firm with 1,000 or more employees pays a wage $13 \%$ higher in

\footnotetext{
${ }^{1}$ Recently, Gibson and Stillman (2009) in the attempt to take into account hard-to-measure workers' abilities, use the International Adult Literacy Survey (OECD) dataset, reporting for nine countries adults' abilities along four skill domains: prose and document literacy, numeracy and problem-solving. They find that large firm wage premiums are quantitatively relevant and statistically significant and are almost unchanged when controlling for these measures of abilities, discarding the explanation based on unmeasured labor qualities.
} 
individual fixed effects estimates, while we find a $27 \%$ higher wages in estimates controlling for individual characteristics.

When we use the sample of workers displaced by plant closings, we find wage premiums paid by large firms similar in magnitude to those estimated with fixed effects on the whole sample, confirming that larger firms pay higher wages in part for unmeasured workers' abilities and in part for true size effects.

The paper is organized as follows. Section 2 presents the datasets used and some descriptive statistics. In Section 3 we carry out the empirical analysis with fixed effects estimates. Section 4 is devoted to estimate firm size effects exploiting exogenous job changes. Section 5 concludes.

\section{The Data}

The dataset used for our empirical analysis is the public-use version of Work Histories Italian Panel (WHIP), provided by LABORatorio Revelli (Turin) and drawn from administrative records of the National Institute of Social Security (INPS). ${ }^{2}$ WHIP is a panel of private firms employees ${ }^{3}$ followed for the years from 1985 to 2004, a 1:180 random sample of the universe of employees constituting more than 1,000,000 observations (about 60,000 individuals per year). WHIP reports information on worker's age, gender, professional qualification, gross annual wage, start and end dates of each job, geographical area of work, number of yearly work days, firm size categories (1-9 employees; 10-19; 20-199; 200-999; 1000 or more), sector of activity, etc. Unfortunately, no information on educational attainment is available in the dataset.

We focus on employees between 16 and 64 years old, blue and white-collars (excluding apprentices and managers). Employees working in a year for less than 3 months (corresponding for administrative reasons to 78 workdays) are excluded. In addition, we exclude from our sample parttime employees, employees on maternity leave, on redundancy pay (CIG), and eliminate observations with missing values on firm size, employment qualification, geographical location, industry. ${ }^{4}$

We do not observe hours of work but we observe full time equivalent days for each year and we calculate the daily wage by dividing the yearly wages by the number of workdays. Wages are deflated using the ISTAT consumer price index (at 2000 prices). To avoid outliers, we also eliminate observations with daily wages below the 0.1 percentile $(€ 11.5)$ and above the 99.9 percentile ( $€$ 257.7). We build Tenure of workers for each year as the difference between the end of the year and the date of hiring in the current firm. ${ }^{5}$ Experience represents the time from the date of entry in the labor market and the current period and it is calculated similarly to Tenure. ${ }^{6}$

\footnotetext{
${ }^{2}$ See the website www.laboratoriorevelli.it/whip/.

${ }^{3}$ Self-employed, public employees or agriculture employees are not represented in the WHIP dataset.

${ }^{4}$ Firm size is not available for the years 2003 and 2004.

${ }^{5}$ Alternatively, between the date of firing and the date of hiring if job match is destroyed during the year.

${ }^{6}$ Since we have no information prior to 1985 on labor market experience, Tenure and Experience are censored for workers hired before the year 1985 .
} 
We end up with a sample of 746,437 observations regarding 103,772 individuals.

The second dataset we use - elaborated by the Fondazione Rodolfo Debenedetti (FRDB) ${ }^{7}$ - is very similar to the WHIP dataset. These data have been produced from the same administrative source (INPS). The relevant difference is that in the FRDB over the years 1997-2002 is available the information on the firm status, reporting if the firm is active or has been closed. ${ }^{8}$ We exploit this information to build a sample of workers displaced because of plant closures. Job changes in this sample should be less affected by endogeneity problems (Gibbons and Katz, 1992).

In Table 1 we show descriptive statistics referring to the WHIP dataset, separating worker characteristics by firm size categories. $28.5 \%$ are females, the average age is 36.4 . Blue collars are 64\%. About $61 \%$ are from Northern regions, while $20 \%$ are from the South. Manufacturing workers are $51 \%$, Commerce 15\%, Financial intermediation 11\%, Transport and communication $7 \%$ (not reported).

About $25 \%$ are employed in firms with 1-9 employees, $13 \%$ in firms with $10-19$ employees; $31 \%$ are in firms with 20-199 employees, $14 \%$ in firms 200-999 employees and 17\% are in firms with more than 1,000 employees. From Table 1 we see that wages strongly increase with firm size. Females work mainly in small firms. Workers are older and have higher experience and tenure in larger firms. Blue-collars are mainly concentrated in small firms.

Table 1. Descriptive Statistics and Breakdown by Firm Size.

\begin{tabular}{|c|c|c|c|c|c|c|}
\hline & \multicolumn{5}{|c|}{ Firm Size Categories } & \multirow{2}{*}{ All firms } \\
\hline & $1-9$ & $10-19$ & 20-199 & 200-999 & $>=1000$ & \\
\hline Wage (daily) & 52.819 & 56.907 & 63.530 & 74.347 & 86.102 & 65.437 \\
\hline Female & 0.337 & 0.325 & 0.291 & 0.255 & 0.197 & 0.285 \\
\hline Age & 33.601 & 34.678 & 36.325 & 38.358 & 40.342 & 36.416 \\
\hline Tenure & 3.848 & 4.415 & 5.319 & 7.022 & 9.571 & 5.813 \\
\hline Experience & 6.945 & 7.542 & 8.217 & 9.123 & 10.684 & 8.369 \\
\hline Blue-collar & 0.706 & 0.736 & 0.690 & 0.587 & 0.440 & 0.643 \\
\hline White-collar & 0.294 & 0.264 & 0.310 & 0.413 & 0.560 & 0.357 \\
\hline North & 0.548 & 0.601 & 0.653 & 0.672 & 0.574 & 0.609 \\
\hline Center & 0.201 & 0.199 & 0.178 & 0.174 & 0.219 & 0.193 \\
\hline South & 0.251 & 0.200 & 0.169 & 0.155 & 0.208 & 0.198 \\
\hline Observations & 183,512 & 99,330 & 231,199 & 101,952 & 130,444 & 746,437 \\
\hline
\end{tabular}

Notes: WHIP dataset. Years=1985-2002.

\footnotetext{
${ }^{7}$ See the website: $w w w . f r d b . o r g$

${ }^{8}$ Another relevant difference is that firm size in the FRDB dataset is a continuous variable.
} 


\section{Firm Size Effects on Wages}

To evaluate the firm size effect on wages, we estimate by OLS the following model:

$$
\ln \left(W_{i t}\right)=\sum_{k=2}^{5} \beta_{k} \operatorname{Size}_{(k) i t}+\phi X_{i t}+\gamma F_{i t}+\mu_{i}+\lambda_{t}+\varepsilon_{i t}
$$

where $W_{i t}$ represents the (daily) wage level of worker $i$ in year $t(t=1985 . .2002) ; \operatorname{Size}_{(k) i t}(k=2 . .5)$ are four dummies for the firm size categories described above (the size class with 1-9 employees represents the reference category); $X_{i t}$ is a vector of time-variant individual characteristics; $F_{i t}$ is a vector of firm characteristics such as geographical location (5 categories) and industry (10 categories); $\mu_{i}$ are individual fixed effects; $\lambda_{t}$ are year dummies; $\varepsilon_{i t}$ is an error term capturing idiosyncratic shocks or unobserved worker characteristics.

In all the estimates we run, standard errors are corrected for heteroskedasticity and adjusted for clustering at the individual level.

Firstly, we run a simple OLS regression of (log) wages on 4 dummies for firm-size classes without controls (column 1, Table 2). In column (2) we control for gender, age, tenure, tenure squared, experience, experience squared, professional qualifications, industrial sectors, regions, yearly dummies (column 2, Table 2). Results show that, controlling for individual characteristics, there is a huge effect of firm size: with respect to the reference category, a firm with 20-199 employees pays a wage $11 \%$ higher, a firm with 200-999 employees pays $20 \%$ more and a firm with more than 1,000 employees pays a wage higher of $27 \% .^{9}$ By comparing firm size effects in specifications (1) (without controls) and (2) it emerges that a considerable share of the large size firm premium can be attributed to workers' observable characteristics.

In column (3) of Table 2 we estimate the wage regression using individual fixed effects to remove the impact of employee-specific time invariant factors. Firm size effects are still positive and highly significant but their magnitude is reduced by about half. For example, a firm with 200 employees pays nearly $10 \%$ more, while a firm with more than 1,000 employees pays higher wages of about $13.4 \%$.

A typical and well-known problem with fixed effects estimates is that measurement errors are exacerbated and these could bias downward the estimates. However, since our data come from administrative sources, they are relatively less affected by measurement errors with respect to other analyses based on surveys of workers or employers.

\footnotetext{
${ }^{9}$ These estimates are in line with those found for UK and USA. For example, in the United States an employee in a firm with 250 employees or more gain a wage $51 \%$ higher than employees in the smallest firms (with less than 10 employees). Controlling for individual characteristics, the effect is around 30\% (see Manning, 2003, p. $85)$.
} 
Our findings imply that individual unobserved abilities are able to explain a sizable share (about 50\%) of the firm size effect in OLS estimates, while about one half can be attributed to firm characteristics.

Table 2. The Impact of Firm Size on Wages. OLS estimates. Dependent Variable: $\ln ($ Wage $)$

\begin{tabular}{|c|c|c|c|}
\hline & (1) & (2) & (3) \\
\hline Firm Size 10-19 & $\begin{array}{c}0.0631 * * * \\
(0.0022)\end{array}$ & $\begin{array}{c}0.0559 * * * \\
(0.0019)\end{array}$ & $\begin{array}{c}0.0276^{* * *} * \\
(0.0015)\end{array}$ \\
\hline Firm Size 20-199 & $\begin{array}{c}0.1546 * * * \\
(0.0022)\end{array}$ & $\begin{array}{c}0.1100 * * * \\
(0.0019)\end{array}$ & $\begin{array}{c}0.0579 * * * \\
(0.0019)\end{array}$ \\
\hline Firm Size 200-999 & $\begin{array}{c}0.3094 * * * \\
(0.0031)\end{array}$ & $\begin{array}{c}0.2011 * * * \\
(0.0026)\end{array}$ & $\begin{array}{c}0.0966 * * * \\
(0.0027)\end{array}$ \\
\hline Firm Size $>=1000$ & $\begin{array}{c}0.4684 * * * \\
(0.0028)\end{array}$ & $\begin{array}{c}0.2698 * * * \\
(0.0027)\end{array}$ & $\begin{array}{c}0.1340 * * * \\
(0.0032)\end{array}$ \\
\hline Female & & $\begin{array}{c}-0.2009 * * * \\
(0.0018)\end{array}$ & \\
\hline Age & & $\begin{array}{c}0.0043 * * * \\
(0.0001)\end{array}$ & $\begin{array}{c}0.0210 * * * \\
(0.0008)\end{array}$ \\
\hline Tenure & & $\begin{array}{c}0.0110 * * * \\
(0.0005)\end{array}$ & $\begin{array}{c}0.0072 * * * \\
(0.0003)\end{array}$ \\
\hline Tenure Squared & & $\begin{array}{c}-0.0003 * * * \\
(0.0000)\end{array}$ & $\begin{array}{l}-0.0000 \\
(0.0000)\end{array}$ \\
\hline Experience & & $\begin{array}{c}0.0106 * * * \\
(0.0005)\end{array}$ & $\begin{array}{l}-0.0012 \\
(0.0009)\end{array}$ \\
\hline Experience Squared & & $\begin{array}{c}-0.0001 * * * \\
(0.0000)\end{array}$ & $\begin{array}{c}-0.0004 * * * \\
(0.0000)\end{array}$ \\
\hline Blue Collar & & $\begin{array}{c}-0.2905 * * * \\
(0.0021)\end{array}$ & $\begin{array}{c}-0.0945 * * * \\
(0.0027)\end{array}$ \\
\hline North-East & & $\begin{array}{c}-0.0181 * * * \\
(0.0020)\end{array}$ & $\begin{array}{l}-0.0029 \\
(0.0065)\end{array}$ \\
\hline Centre & & $\begin{array}{c}-0.0283 * * * \\
(0.0023)\end{array}$ & $\begin{array}{l}-0.0075 \\
(0.0068)\end{array}$ \\
\hline South & & $\begin{array}{c}-0.0478 * * * \\
(0.0025)\end{array}$ & $\begin{array}{c}-0.0126^{*} \\
(0.0073)\end{array}$ \\
\hline Islands & & $\begin{array}{c}-0.0579 * * * \\
(0.0038)\end{array}$ & $\begin{array}{l}-0.0166 \\
(0.0102)\end{array}$ \\
\hline Individual Fixed Effects & NO & NO & YES \\
\hline Observations & 746437 & 746437 & 746437 \\
\hline $\mathrm{R}$-squared & 0.2101 & 0.4697 & 0.2093 \\
\hline Number of Individuals & & & 103772 \\
\hline
\end{tabular}

Notes: The Table reports OLS estimates. In all the regressions we control for 18 year dummies and 10 industry dummies (not reported). Standard errors, corrected for heteroskedasticity and adjusted for clustering at the individual level, are reported in parentheses. The symbols $* * *, * * *$ indicate that coefficients are statistically significant, respectively, at the 1,5 , and 10 percent level. Source: WHIP data.

In order to obtain a summary measure of the effect of firm size on wages, that is, the firm sizewage elasticity, following a common practice we impute to each firm size category a continuous measure of size, Firm Size, using the midpoint of the size classes ${ }^{10}$ (see Manning, 2003; Brown and Medoff, 1989). Albæk et al. (1998) confirm that this practice has negligible consequences in terms of measurement errors.

\footnotetext{
${ }^{10}$ Firms in the largest class are attributed the double of the category's threshold.
} 
We regress the (log) wage on the logarithm of Firm Size. Therefore, the coefficient represents the elasticity of wage with respect to the firm size. Estimates of the same specifications in Table 2 are reported in Table 3. An employee moving to a firm with a double size increases his wage of about $4.3 \%$, controlling for individual characteristics (column 2). Using individual fixed effects (column 3), the increase in wage is $2.0 \%$.

Table 3. The Elasticity of Wages to Firm Size. Firm Size measured continuously. OLS estimates. Dependent Variable: $\ln ($ Wage $)$

(1) (2) (3)

\begin{tabular}{lccc}
\hline Log (Firm Size) & $\begin{array}{c}0.0738 * * * \\
(0.0004)\end{array}$ & $0.0429 * * *$ & $0.0205^{* * *}$ \\
& & $(0.0004)$ & $(0.0005)$ \\
Controls & NO & YES & YES \\
Individual Fixed Effects & NO & & YES \\
Observations & 746437 & 746437 & 746437 \\
R-squared & 0.1992 & 0.26044 & 0.2089 \\
Number of Individuals & & & 103772 \\
\hline \hline
\end{tabular}

Notes: see Table 2.

Results are in line with those obtained in other countries. Brown and Medoff (1989) estimate an elasticity ranging from 2.1 to 3.2. Manning (2003) shows that the elasticity for US is $6.4 \%$ controlling for individual characteristics, while the same author finds an elasticity of $1.3 \%$ for UK using individual fixed effects. Albæk et al. (1998), using cross-section data for Nordic countries, find that controlling for many individual and employer characteristics, the firm size wage elasticity ranges between 2 and 3 percent.

Both in Table 2 and 3 it clearly emerges that the estimated size-wage differential is reduced by about 50 percent when using individual fixed effects. However, the component imputable to firm characteristics remains quite considerable.

The differences between cross-sectional and fixed effects estimates are in line with the findings of Winter-Ebmer and Zweimüller (1999) for Switzerland, while we find a higher percentage attributable to firm characteristics with respect to Abowd, Kramarz and Margolis (1999) who argue that individual heterogeneity effects explain about $75 \%$ of the firm-size wage effect, while firm effects explain relatively little.

\section{Distinguishing the Effect on Movers from Firm Size Variations}

The effect of firm size on wages in estimates of Tables 2 and 3 is identified by two distinct variations: 1) growth or contraction of the size of a firm over time (employees do not change firms); 2) workers moving from one firm to another of different size. In this section we investigate if these two types of variations produce similar effects on wages (Brown and Medoff, 1989; Winter-Ebmer and Zweimüller, 1999). 
To identify the first effect, that is, the change in size of the same firm, instead of using employee fixed effects, we use fixed effects for each specific job match between a given firm and a given worker. Estimates are reported in Table 4, column 1: in this regression, the firm-size effect is identified only by changes in the size of the same firm. The firm size elasticity is estimated at 1.15 percent (statistically significant at the 1 percent level).

Alternatively, to estimate the impact on wages of firms changing their size, we focus on a sample of "stayers" (workers who never changed their firm). Almost half of the sample workers $(341,445)$ did not change their firm in the period under examination. On this sample, we estimate the effects of firm size with employee fixed effects. In this case, the firm size elasticity is estimated at about $1.24 \%$ (Table 4, column 2).The results of the two procedures are very similar.

The estimate of the impact on wages of firm size variations should be less affected by selfselection bias, since the change in size is typically not affected by worker individual decisions (exogenous variation). On the other hand, the estimated effect on workers who do not change firm could be affected by the existence of some inertia in a firm's contractual structure.

In order to identify the effect of firm size when a worker moves between firms of different size, we build a sample by excluding all the firms that have changed their size over the period considered. Then, we estimate on this sample with employee fixed effects (Table 4, column 3). Alternatively, we exclude from our sample all the stayers (as defined above) and estimate only on workers moving at least once (Table 4, column 4). The two procedures lead to very similar results: the effect of the firm size for workers moving between firms is considerable higher: the elasticity is 2.1$2.3 \%$, again significant at the 1 percent level.

In the next Section we directly address the problem of endogenous job changes, that could bias even fixed effects estimates.

Table 4. The Elasticity of Wages to Firm Size Distinguishing between Stayers and Movers. Dependent Variable: $\ln ($ Wage $)$
(1)
(2)
(3)
(4)

\begin{tabular}{|c|c|c|c|c|}
\hline Log (Firm Size) & $\begin{array}{c}0.0115 * * * \\
(0.0006)\end{array}$ & $\begin{array}{c}0.0124 * * * \\
(0.0009)\end{array}$ & $\begin{array}{c}0.0230 * * * \\
(0.0006)\end{array}$ & $\begin{array}{c}0.0207 * * * \\
(0.0005)\end{array}$ \\
\hline Controls & $\begin{array}{c}\text { YES } \\
\text { Fixed effects for } \\
\text { each job match }\end{array}$ & $\begin{array}{c}\text { YES } \\
\text { Individual fixed } \\
\text { effects }\end{array}$ & $\begin{array}{c}\text { YES } \\
\text { Individual fixed } \\
\text { effects }\end{array}$ & $\begin{array}{c}\text { YES } \\
\text { Individual fixed } \\
\text { effects }\end{array}$ \\
\hline Sample & & Only Stayers & $\begin{array}{l}\text { Excluding firms } \\
\text { that changed their } \\
\text { size }\end{array}$ & Only Movers \\
\hline Observations & 746437 & 341445 & 547324 & 404992 \\
\hline $\mathrm{R}$-squared & 0.239 & 0.274 & 0.196 & 0.191 \\
\hline Number of individuals & & 58768 & 92648 & 45004 \\
\hline
\end{tabular}

Notes: The Table reports OLS estimates. In all the regressions we control for 18 year dummies and 10 industry dummies (not reported). Standard errors, corrected for heteroskedasticity and adjusted for clustering at the individual level, are reported in parentheses. The symbols $* * *, * * *$ indicate that coefficients are statistically significant, respectively, at the 1,5 , and 10 percent level. Source: WHIP data. 


\section{Firm Size Effects Exploiting Exogenous Job Changes}

Fixed effects estimates identify the impact of firm size on the basis of wages paid to workers moving from employers of different size. The implicit assumption is that job changes are exogenous.

Since many job changes are voluntary, one may question that the endogeneity of job changes leads to inconsistent estimators even using individual fixed effects (Gibbons and Katz, 1992; Solon, 1988). Gibbons and Katz (1992) propose a simple theoretical model showing that under the assumptions that unmeasured abilities could not be equally valued in firms of different categories and that information about individual abilities is imperfect initially but improves over time, workers could move from one type of firm to another generating variations in wages that mimic true firm effects even if there is only heterogeneity among individuals and no firm effects.

In this section we try to face this problem following the empirical approach that Gibbons and Katz (1992) have adopted to estimate inter-industry wage differentials.

We use the INPS administrative data provided by the Fondazione Rodolfo Debenedetti (FRDB). The data are very similar to the WHIP dataset but for our purposes we can only use the sample 1997-2002 because the information on firm status (active, suspended, ${ }^{11}$ closed) is available only for these years. A further difference with the WHIP dataset is that firm size is a continuous measure.

We follow the same criteria explained in Section 2 to select our sample of workers. Preliminarily, to verify that the WHIP and FRDB datasets are consistent, we replicate on the whole sample of FRDB the estimates reported in Tables 2 and 3, finding that there are no substantial differences (see Appendix).

We then focus on displaced workers. We know the month and the year in which a firm has been closed or suspended and the exact date in which a worker has been displaced. In the sample of displaced workers we include only the workers separating from their firm in the same month the firm has closed or suspended or in the two previous months. ${ }^{12}$

To identify the firm size effect we exploit the changes between post-displacement and predisplacement earnings occurring for workers moving between firms of different size. Given the characteristics of our dataset, we focus on displaced workers who subsequently find a new job in a private firm, so we do not consider individuals who remained unemployed, or who became selfemployed, public employees or agriculture employees. To avoid spurious wages changes, we also exclude from the estimates the observations referring to the year of displacement.

We end up with a sample of about 6,500 displaced workers, including 25,000 observations.

\footnotetext{
${ }^{11}$ Defined as firms with activity temporarily suspended (without employees) with intention to hire somebody again in the future.

${ }^{12}$ Firms who are going to close typically do not dismiss all their workers contemporaneously at the moment of closure. As a robustness check, we have also experimented considering as displaced (a) the workers separated from their firm in the same month of the closure or (b) leaving their job 6 months before the closure of the firm. In both cases, using these alternative samples we obtain very similar results to those shown in Table 5.
} 
Estimates of equation [1] in several specifications are reported in Table 5. In Panel (A) we show the estimates considering the five firm size categories while in Panel (B) we use as explanatory variable the firm size (in log) in continuous form. In column (1) we estimate a basic specification without controls, while in column (2) we include individual controls. Individual fixed effects estimates are reported in column (3).

Along the different specifications, the estimates on the sample of exogenous job changes are not very different from the estimates on the whole sample. Fixed effects estimates show that a displaced worker earns a wage of 5.2 percent higher in a firm with 20-199 employees (with respect to a firm with 1-9 employees), while the wage is 13 percent higher in a firm with more than 1,000 employees. Firm size wage differentials are always highly significant. As regards the elasticity of wages to firm size (Panel B) we find a figure of about $2.7 \%$ controlling for individual characteristics, while it becomes $2.1 \%$ when we estimate using individual fixed effects (significant at the 1 percent level). It is worthwhile to note that if the large firm premium was exclusively due to the sorting of workers, we should find no significant coefficients on firm size.

In columns (4)-(6) we further restrict our sample focusing only on workers employed for at least two years in a firm that eventually closed, and for at least two years in a new firm. Results are very similar.

In sum, workers displaced by the closure of small firms moving to large firms experience a wage gain, while workers fired by large firms and moving to smaller firms experience a wage loss.

Comparing cross-sectional (columns 2 and 5) with individual fixed effects estimates (columns 3 and 6) we confirm that individual heterogeneity is able to explain about 50-60\% of the firm-size wage differentials found in cross-sectional estimates. Therefore, unobservable individual traits explain only a fraction of the variations, but a considerable share can be attributed to true firm effects.

It is interesting to note that since the estimates on the whole sample of workers are similar to the estimates obtained on the sample of displaced workers, the problem of endogenous job changes do not seem create relevant biases. 
Table 5. Firm Size Effects on the sample of workers displaced by firm closures. Fondazione Debenedetti - 1997-2002.

\begin{tabular}{|c|c|c|c|c|c|c|}
\hline & $\begin{array}{l}(1) \\
\text { All }\end{array}$ & $\begin{array}{l}(2) \\
\text { All }\end{array}$ & $\begin{array}{l}\text { (3) } \\
\text { All }\end{array}$ & $\begin{array}{c}(4) \\
\text { 2-year } \\
\text { window }\end{array}$ & $\begin{array}{c}(5) \\
\text { 2-year } \\
\text { window }\end{array}$ & $\begin{array}{c}(6) \\
\text { 2-year } \\
\text { window }\end{array}$ \\
\hline \multicolumn{7}{|c|}{ Panel A } \\
\hline Firm Size 10-19 & $\begin{array}{c}0.0863 * * * \\
(0.0099)\end{array}$ & $\begin{array}{c}0.0687 * * * \\
(0.0087)\end{array}$ & $\begin{array}{c}0.0376 * * * \\
(0.0072)\end{array}$ & $\begin{array}{c}0.0791 * * * \\
(0.0113)\end{array}$ & $\begin{array}{c}0.0674 * * * \\
(0.0101)\end{array}$ & $\begin{array}{c}0.0340 * * * \\
(0.0099)\end{array}$ \\
\hline Firm Size 20-199 & $\begin{array}{c}0.1369 * * * \\
(0.0102)\end{array}$ & $\begin{array}{c}0.0971 * * * \\
(0.0089)\end{array}$ & $\begin{array}{c}0.0520 * * * \\
(0.0084)\end{array}$ & $\begin{array}{c}0.1391 * * * \\
(0.0117)\end{array}$ & $\begin{array}{c}0.0983 * * * \\
(0.0103)\end{array}$ & $\begin{array}{r}0.0558 * * * \\
(0.0113)\end{array}$ \\
\hline Firm Size 200-999 & $\begin{array}{c}0.2743 * * * \\
(0.0177)\end{array}$ & $\begin{array}{c}0.1662 * * * \\
(0.0136)\end{array}$ & $\begin{array}{c}0.0721 * * * \\
(0.0123)\end{array}$ & $\begin{array}{c}0.3007 * * * \\
(0.0184)\end{array}$ & $\begin{array}{c}0.1798 * * * \\
(0.0147)\end{array}$ & $\begin{array}{c}0.0579 * * * \\
(0.0179)\end{array}$ \\
\hline Firm Size $>=1000$ & $\begin{array}{c}0.2277 * * * \\
(0.0193)\end{array}$ & $\begin{array}{c}0.1355^{* * *} \\
(0.0169)\end{array}$ & $\begin{array}{c}0.1303 * * * \\
(0.0155)\end{array}$ & $\begin{array}{c}0.2538 * * * \\
(0.0216)\end{array}$ & $\begin{array}{c}0.1274 * * * \\
(0.0187)\end{array}$ & $\begin{array}{c}0.0923 * * * \\
(0.0193)\end{array}$ \\
\hline Observations & 25852 & 25840 & 25840 & 15744 & 15740 & 15740 \\
\hline R-squared & 0.0432 & 0.3233 & 0.0630 & 0.0511 & 0.3255 & 0.0471 \\
\hline Number of Individuals & & & 6558 & & & 6208 \\
\hline Controls & NO & YES & YES & NO & YES & YES \\
\hline Individual Fixed Effects & NO & NO & YES & NO & NO & YES \\
\hline \multicolumn{7}{|c|}{ Panel B } \\
\hline Log (Firm Size) & $\begin{array}{c}0.0433 * * * \\
(0.0023)\end{array}$ & $\begin{array}{c}0.0272 * * * \\
(0.0020)\end{array}$ & $\begin{array}{c}0.0211 * * * \\
(0.0022)\end{array}$ & $\begin{array}{c}0.0472 * * * \\
(0.0025)\end{array}$ & $\begin{array}{c}0.0279 * * * \\
(0.0022)\end{array}$ & $\begin{array}{c}0.0203 * * * \\
(0.0032)\end{array}$ \\
\hline Observations & 25367 & 25356 & 25356 & 15484 & 15480 & 15480 \\
\hline R-squared & 0.0457 & 0.3209 & 0.0648 & 0.0544 & 0.3250 & 0.0503 \\
\hline Number of Individuals & & & 6543 & & & 6162 \\
\hline Controls & NO & YES & YES & NO & YES & YES \\
\hline Individual Fixed Effects & NO & NO & YES & NO & NO & YES \\
\hline
\end{tabular}

Notes: The Table reports OLS estimates. In all the regressions we control for 6 year and 10 industry dummies (not reported). In columns (4)-(6) we focus on a two-year window around displacement. Standard errors, corrected for heteroskedasticity and adjusted for clustering at the individual level, are reported in parentheses. The symbols $* * *, * *, *$ indicate that coefficients are statistically significant, respectively, at the 1, 5, and 10 percent level. Source: Fondazione Rodolfo DeBenedetti dataset (19972002).

\section{Asymmetric Effects of Firm Size Variations}

As a further check that workers' movements across firms are not endogenous when considering displaced workers, we measure the impact on wages of firm size variations distinguishing between positive and negative variations of firm size.

To this aim, we build a variable to capture positive variations of firm size as:

$$
\Delta \ln \left(\text { Firm Size }_{i t}\right)^{(+)}=\max \left\{\Delta \ln \left(\text { Firm Size }_{i t}\right), 0\right\}
$$

which takes positive values for movements of employees towards larger firms (and zero for movements towards smaller firms or towards firms with equal size).

Similarly, we define:

$$
\Delta \ln \left(\text { Firm Size }_{i t}\right)^{(-)}=\min \left\{\Delta \ln \left(\text { Firm Size } e_{i t}\right), 0\right\}
$$


which takes negative values for movements of employees towards smaller firms (and zero for movements towards larger firms or towards firms with equal size). ${ }^{13}$

Then, we estimate:

$$
\Delta \ln \left(W_{i t}\right)=\beta_{1} \Delta \ln \left(\text { Firm Size }_{i t}\right)^{(+)}+\beta_{2} \Delta \ln \left(\text { Firm Size }_{i t}\right)^{(-)}+\phi \Delta X_{i t}+\gamma \Delta F_{i t}+v_{i t}
$$

In Table 6 we report the OLS estimates of equation [2] on the sample of displaced workers, first without controls (column 1) and then with individual controls (column 2). Time invariant individual components are removed by taking differences.

Considering the specification with a full set of controls (column 2), we show that the elasticity of wages to firm size is $1.82 \%$ when the worker moves towards a larger firm, while the worker experience a loss of about $2.24 \%$ when he moves to a smaller firm. Both these effects are highly statistically significant. We test if the magnitude of the wage variations are equal and we are not able to reject the null hypothesis of equality $(p$-value $=0.289)$.

Table 6. Asymmetric Effects of Firm Size Variations. Sample of displaced workers. OLS estimates. Dependent Variable: $\Delta \ln ($ Wage $)$

\begin{tabular}{lcc}
\hline$\Delta \ln ($ FirmSize $)>0$ & $0.0232 * * *$ & $0.0182 * * *$ \\
& $(0.0025)$ & $(0.0025)$ \\
$\Delta \ln ($ FirmSize $)<0$ & $0.0287 * *$ & $0.0224 * * *$ \\
& $(0.0033)$ & $(0.0033)$ \\
Controls & $\mathrm{NO}$ & YES \\
Observations & 25367 & 25356 \\
R-squared & 0.018 & 0.056 \\
$p$-value & 0.243 & 0.304 \\
\hline \hline Notes: The Table reports OLS estimates. Individual controls are those used in column 2 of Table 2 with 6 \\
year dummies and 10 industry dummies. Standard errors, corrected for heteroskedasticity and adjusted for \\
clustering at the individual level, are reported in parentheses. The symbols *** indicates that coefficients \\
are statistically significant at the 1 percent level. Source: Fondazione Rodolfo DeBenedetti dataset (1997- \\
2002).
\end{tabular}

\section{Concluding Remarks}

We have investigated the extent and the determinants of firm size wage differentials in the Italian labor markets using two large datasets based on administrative sources.

We firstly estimate a standard model controlling for individual characteristics finding that employees of large firms earn a wage $27 \%$ higher than small firm employees. Using individual fixed effects to take into account unobservable worker characteristics, we find that large firms pay about $13 \%$ more than smaller firms or that the wage increases of about $2 \%$ when the size of the firm doubles. Comparing estimates in pooled models with fixed effects estimates, we show that about one-half of the observed firm size wage differentials in pooled data with individual controls are not caused by unobserved individual abilities but are true firm size effects.

\footnotetext{
${ }^{13}$ For a similar approach in another context see Borenstein, Cameron, and Gilbert (1997).
} 
Our findings are in line with the estimates of Winter-Ebmer and Zweimüller (1999) finding for Swiss labor markets more or less the same shares attributable to unmeasured individual abilities and to firm size effects. On the other hand, our results are in contrast to Abowd, Kramarz and Margolis (1999) who attribute almost the whole firm size effect to unobserved individual characteristics.

Since with individual fixed effects we identify the wage differentials between large and small firms from workers moving between firms and since moving workers could be a self-selected sample giving rise to inconsistent estimates, in the second part of the paper we focus on a sample of workers displaced because of the closure of their firms. We exploit a unique characteristic of the FRDB dataset, containing information on whether a firm is active or has been closed.

Replicating our estimation strategies on this sample, we substantially confirm the findings obtained on the whole sample: individual unmeasured abilities explain about one-half of the firm size wage premium, whereas the other half can be ascribed to firm size characteristics.

Unfortunately, in our datasets we do not observe some relevant firm characteristics (such as profits and capital intensity) and we are not able to relate the wage premium due to firm heterogeneity to some specific characteristics of firms and this remains a topic for future research. ${ }^{14}$

\section{References}

Abowd, J., Kramarz, F. and Margolis, D., (1999), "High Wage Workers and High Wage Firms", Econometrica, Vol. 67, pp. 251-333.

Albeak, K., Arai, M., Asplund, R., Barth, E. and Madsen, E., (1998), "Employer Size Wage Effects in the Nordic Countries", Labour Economics, 5(4), pp. 425-48.

Arai, M., (2003), "Wages, Profits, and Capital Intensity: Evidence from Matched Worker-Firm Data" Journal of Labor Economics, 21, pp. 593-618.

Borenstein, S, Cameron, C., and Gilbert, R., (1997), "Do Gasoline Prices Respond Asymmetrically to Crude Oil Price Changes?" Quarterly Journal of Economics, 112(1): 305-339.

Brown, C. and Medoff, J. (1989), "The Employer Size-Wage Effect", Journal of Political Economy, 97(5), pp. 1027-59.

Brunello G. and Colussi, A. (1998), "The employer size-wage effect: evidence from Italy". Labour Economics, 5:217-230

Gibbons, R. and Katz, L., (1992) "Does Unmeasured Ability Explain Inter-Industry Wage Differentials", Review of Economic Studies, 59, 515-535.

Gibson, J. and Stillman, S., (2009), "Why Do Big Firms Pay Higher Wages? Evidence from an International Database", Review of Economics and Statistics, 91(1), pp. 213-218.

Heckman, J. (1979), "Sample selection bias as a specification error", Econometrica, 47, 153-62.

Hildreth A. K. G. and Oswald A. J. (1997) 'Rent-sharing and Wages: Evidence from Company and Establishment Panels', Journal of Labor Economics, 15: 318-337.

\footnotetext{
${ }^{14}$ However, the explanation of compensating wage differentials paid for worse working conditions in large firms appears rather implausible from the evidence gathered in previous studies. In fact, if large firms paid compensating wage differentials we should observe that, controlling for wages, large firm employees are less satisfied and search more intensely for a new job (see Winter-Ebmer and Zweimüller, 1999). Ponzo (2011) for Italian employees shows that, controlling for wages, there are no significant differences in on-the-job search for workers employed in small and large firms.
} 
Idson T. and Feaster J. (1990) "A selectivity model with employer size wage differentials", Journal of Labor Economics, 8:99-122.

Lallemand, T., Plasman, R. and Rycx, F., (2007), "The establishment-size wage premium: evidence from European countries", Empirica, 34:427-451.

Lee, L. (1978), "Unionism and Wage Rates: A Simultaneous Equations Model with Qualitative and Limited Dependent Variables", International Economic Review, 19, pp. 415-33.

Main, B. and Reilly, B., (1993), "The employer size-wage gap: evidence for Britain”, Economica, 60:125-142

Manning, A. (2003), Monopsony in motion: imperfect competition in labor markets, Princeton University Press, Princeton.

Pedace, R., (2010), "Firm Size-Wage Premiums: Using Employer Data to Unravel the Mystery", Journal of Economic Issues, 1, March, pp. 163-181.

Ponzo, M. (2011), "On-the-job search in Italian labour markets: an empirical analysis", International Journal of the Economics of Business, forthcoming.

Schmidt, C. and Zimmermann, K. (1991), "Work Characteristics, Firm Size and Wages", Review of Economics and Statistics, Vol.73, No.4, pp 705-710.

Solon, G. (1988), "Self-Selection Bias in Longitudinal Estimation of Wage Gaps", Economics Letters, 28(3), pp. 285-90.

Sulis, G., (2011), "What can monopsony explain of the gender wage differential in Italy?", International Journal of Manpower, 32, 4, pp. 446-470.

Troske K. (1999) 'Evidence on the Employer Size-Wage Premium from Worker establishment Matched Data', Review of Economics and Statistics, 81: 15-26

Winter-Ebmer, R. and Zweimüller, J., (1999) "Firm-Size Wage Differentials in Switzerland: Evidence from Job-Changers", American Economic Review, Papers and Proceedings, pp. 89-93. 
APPENDIX

Table A1. Firm Size effects Fondazione Debenedetti. All Sample 1997-2002

\begin{tabular}{|c|c|c|c|}
\hline & $(1)$ & $(2)$ & (3) \\
\hline & \multicolumn{3}{|c|}{ Panel A } \\
\hline \multirow{2}{*}{ Firm Size 10-19 } & $0.0756^{* * *}$ & $0.0455 * * *$ & $0.0140 * * *$ \\
\hline & $(0.0027)$ & $(0.0023)$ & $(0.0019)$ \\
\hline \multirow{2}{*}{ Firm Size 20-199 } & $0.1585^{* * *}$ & $0.0880 * * *$ & $0.0189 * * *$ \\
\hline & $(0.0025)$ & $(0.0021)$ & $(0.0021)$ \\
\hline \multirow[t]{2}{*}{ Firm Size 200-999 } & $0.2994 * * *$ & $0.1703 * * *$ & $0.0388 * * *$ \\
\hline & $(0.0035)$ & $(0.0027)$ & $(0.0025)$ \\
\hline \multirow[t]{2}{*}{ Firm Size $>=1000$} & $0.4371 * * *$ & $0.2587 * * *$ & $0.0543 * * *$ \\
\hline & $(0.0031)$ & $(0.0027)$ & $(0.0027)$ \\
\hline Observations & 660874 & 660362 & 660362 \\
\hline R-squared & 0.1013 & 0.4393 & 0.0511 \\
\hline Number of Individuals & & & 170384 \\
\hline Controls & NO & YES & YES \\
\hline \multirow[t]{2}{*}{ Individual Fixed Effects } & NO & NO & YES \\
\hline & \multicolumn{3}{|c|}{ Panel B } \\
\hline \multirow{3}{*}{$\log ($ Firm Size $)$} & Daily Wage (log) & Daily Wage (log) & Daily Wage (log) \\
\hline & $0.0681 * * *$ & $0.0426 * * *$ & $0.0166 * * *$ \\
\hline & $(0.0004)$ & $(0.0004)$ & $(0.0007)$ \\
\hline Observations & 638015 & 637515 & 637515 \\
\hline R-squared & 0.1297 & 0.4444 & 0.0546 \\
\hline Number of Individuals & & & 168897 \\
\hline Controls & NO & YES & YES \\
\hline Individual Fixed Effects & $\mathrm{NO}$ & $\mathrm{NO}$ & YES \\
\hline
\end{tabular}

